\title{
INTRASPECIFIC VARIATIONS IN THE IVORY FEATHERLEG PLATYCNEMIS DEALBATA (INSECTA: ODONATA) FROM TURKEY
}

\author{
MIROĞLU, A. \\ Fatsa Faculty of Marine Sciences, Ordu University, Fatsa-Ordu, Turkey \\ (e-mail: alimiroglu@gmail.com; phone: +90-452-423-5053; fax: +90-452-423-9953) \\ (Received 20 $0^{\text {th }}$ Dec 2017; accepted $3^{\text {rd }}$ Apr 2018)
}

\begin{abstract}
Intraspecific variations can be observed in many types of animal species in Turkey due to the geographical and ecological characteristics of the region. The aim of this research is to study the Platycnemis dealbata populations in Turkey and to survey how the Anatolian Diagonal affects them. The Platycnemis dealbata specimens were collected from Kahramanmaraş and Iğdır Provinces of Turkey in 2010, 2012, 2015, and 2017. Variations were found between these two populations. The variations seen in the Platycnemis dealbata populations were examined and demonstrated with illustrations.
\end{abstract}

Keywords: Odonata, damselfly, Turkey, taxonomy, biodiversity

\section{Introduction}

The genus Platycnemis is represented by three species ( $P$. pennipes, $P$. kervillei, and $P$. dealbata) in Turkey (Kalkman et al., 2003; Kalkman, 2006). P. dealbata males have enlarged white legs and an ivory body. $P$. dealbata males and females differ from other species ( $P$. pennipes and $P$. kervillei) in this region by the unmarked tibia of the mid and hind legs (Kalkman, 2006; Boudot et al., 2009). P. dealbata can be found from Northwest India through Kashmir and Afghanistan and west to the Caucasus, southeastern Turkey, Iran, Iraq, Lebanon, Israel, Syria and Jordan (Askew, 1988; Steinmann, 1997; Boudot et al., 2009). It is most abundant in Syria, Lebanon, and Israel (Dumont, 1977). The species occurs in southeastern Turkey and in the coastal area in the southeast (but does not occur beyond the Taurus range in the northwest of Turkey) (Kalkman, 2006; Boudot et al., 2009).

Anatolia is located in the Alpine-Himalayan mountain belt between Europe, Asia, Africa, and Arabia. Its landform is primarily due to its geological history of collision of the Arabian and African plates with the European plate, resulting in the closure of the Tethys Sea (Rögl, 1998; Mutun, 2010; Kapli et al., 2013). Because of that, Anatolia experienced the upheaval and folding of the Caucasus and the Taurus Mountains, and the uplift of the Central Anatolian Highlands (Mutun, 2010). Anatolia is considered to be either a bridge or a barrier for species dispersal between Asia, Europe, and the Ethiopian region because of its position and geological history (Kapli et al., 2013).

There is a highland dividing Anatolia, known as the Anatolian Diagonal, and it has been suggested that the Anatolian Diagonal is an important geographic barrier contributing to the current composition of various species across Anatolia and dividing species distribution in the east and west (Davis, 1971; Çıplak et al., 1993; Mutun, 2010). This barrier has isolated many species in East and West Anatolia (Çıplak et al., 1993). Anatolia has a mountainous land and various climate types, so various subpopulations were generated there for all insect groups (Çıplak et al., 1993).

According to Martens (1996), P. dealbata and P. kervillei can be observed to the east of the Anatolian Diagonal, while P. pennipes shows distribution to the west (Fig. 1). P. 
dealbata and P. kervillei show distribution together in Turkey, Syria, Iraq and Iran (the east of Anatolian Diagonal) (Boudot et al., 2009; Kiany et al., 2016; Schneider and Ikemeyer, 2016, 2017).

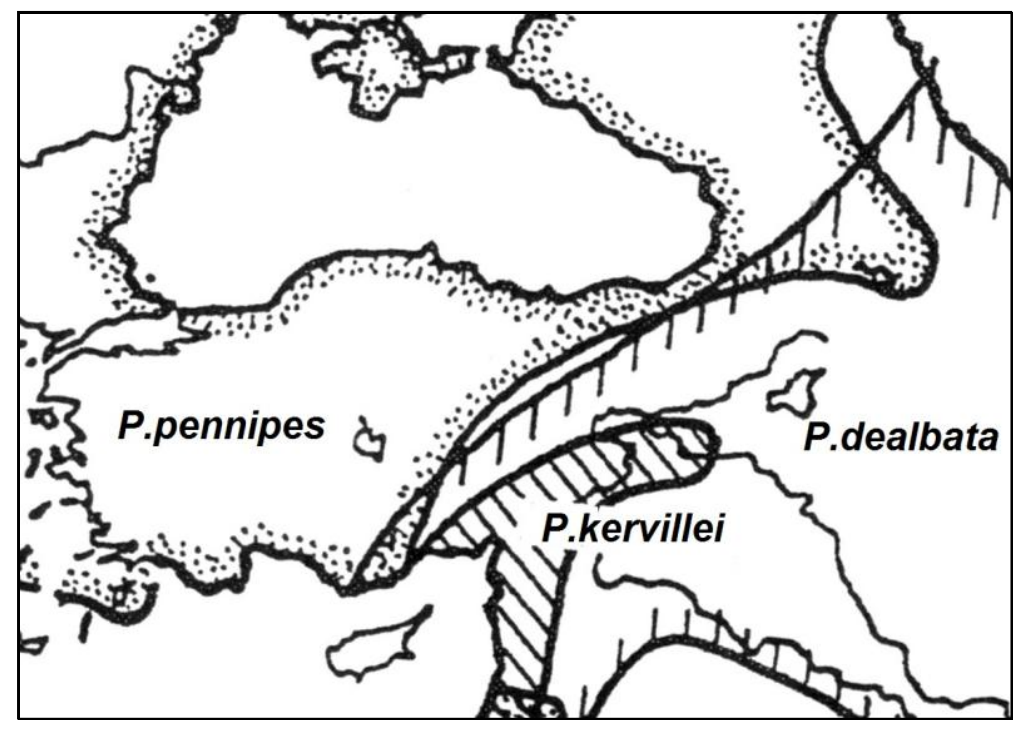

Figure 1. Distribution of genus Platycnemis in Turkey and neighbouring countries (Martens, 1996)

This study is mainly focusing on the populations of the ivory featherleg $P$. dealbata in Turkey and the observed effect of the Anatolian Diagonal on these populations. For this reason, samples were collected from Kahramanmaraş and Iğdır Provinces. As a result of the study, it was determined that there are variations between these two populations and these variations are revealed. It was mentioned that this could be caused by the Anatolian Diagonal.

\section{Material and methods}

The $P$. dealbata specimens were collected and identified from Kahramanmaraş and Iğdır Provinces (Turkey) in 2010, 2012, 2015, and 2017 (Fig. 2). The examined specimens were collected with aerial nets. The habitat consists of running water and is associated with weeds. Relevant literature (Martens, 1996; Dijkstra and Lewington, 2006; Kalkman, 2006) was used for taxonomic examination and identification of the specimens.

The material examined: 52 male and 26 female specimens, collected from Kahramanmaraş (20 male and 12 female specimens) and Iğdır (32 male and 14 female specimens) Provinces, Turkey in 2010, 2012, 2015, and 2017; leg. and det. Miroğlu, A. All materials are deposited in the Museum of Fatsa Faculty of Marine Sciences, Ordu University, Ordu, Turkey.

\section{Results}

The variations of the $P$. dealbata male include spots on the head (especially on the frons), on the abdominal segments (S7-9), and on the pronotum. Its variations have been presented by illustrations (Figs. 3, 4 and 5). In some specimens, these areas are all 
white, while others have black spots. The spreading of the black spots varies from narrow to wide.

When the head is viewed from the dorsal aspect, a weak and continuous or discontinuous black stripe can be seen on the frons (especially between the antennae). In some specimens (especially from Iğdır Province), the black stripe is stretching between the antennae. At the same time, the spreading of the black transverse band on the occiput and on the vertex varies from narrow to wide (Fig. $3 a, b)$.

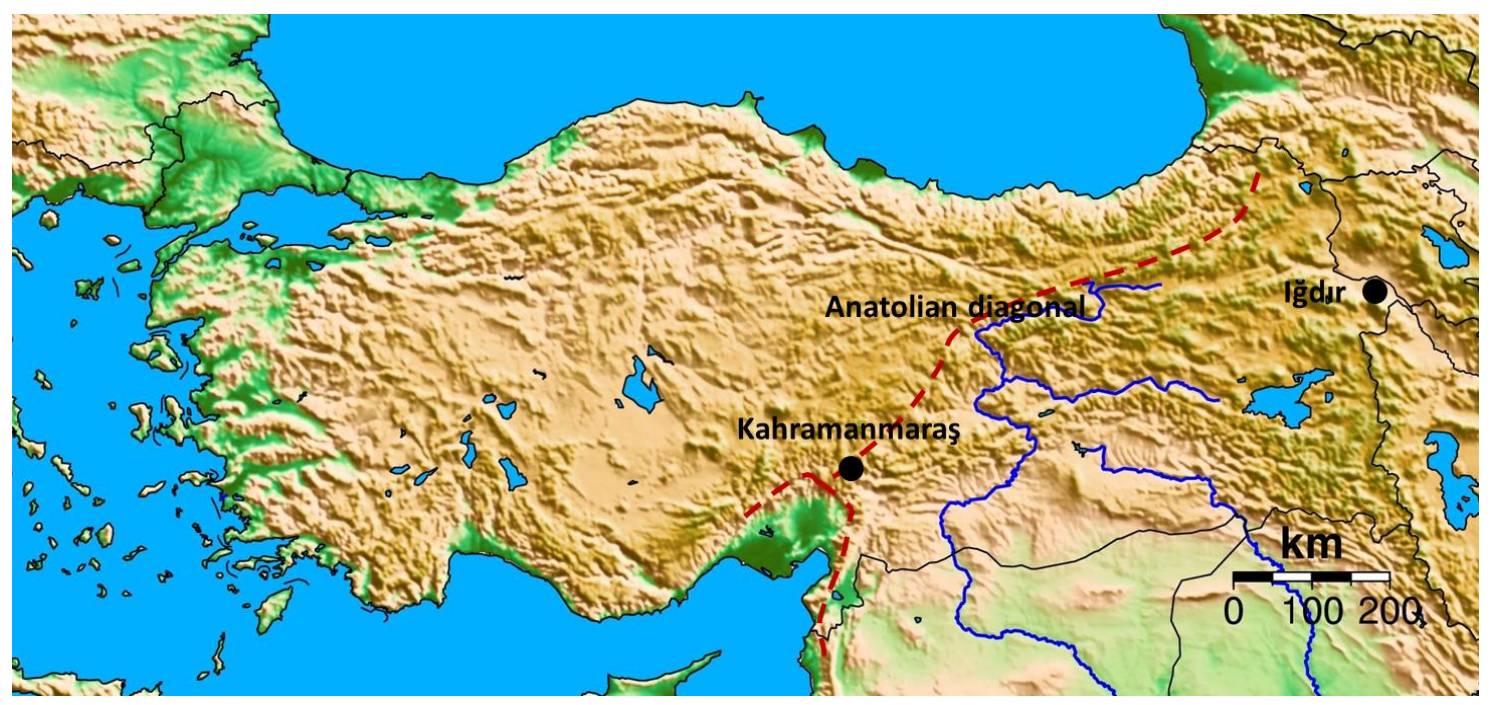

Figure 2. Topographic position of P. dealbata collection localities, with dashed line showing the "Anatolian Diagonal"
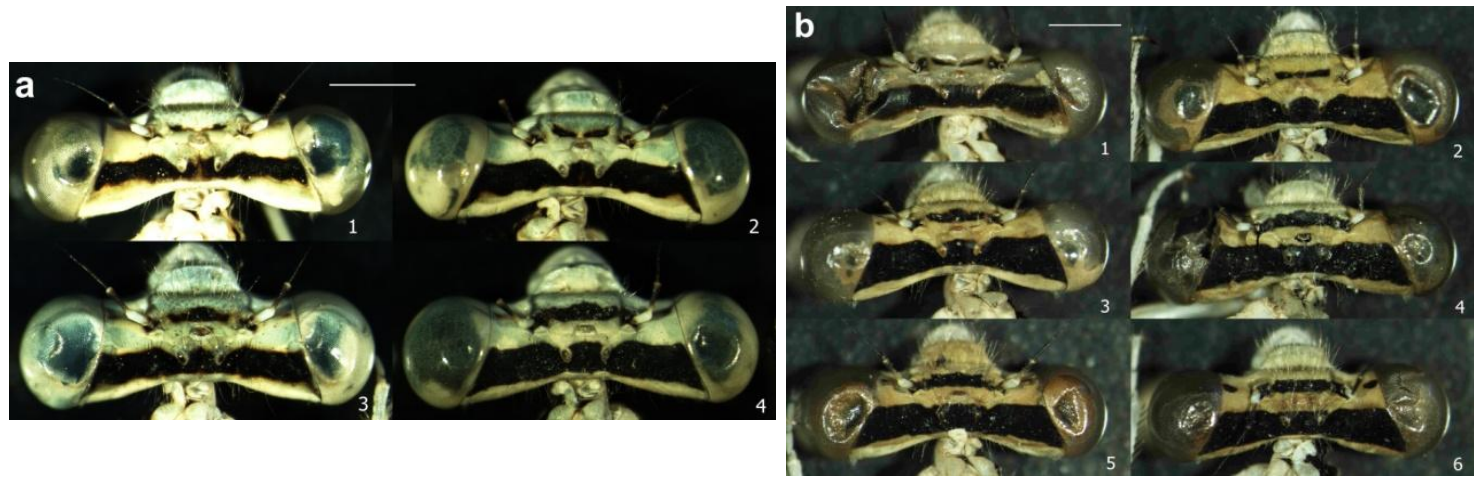

Figure 3. Head dorsal view (a) Kahramanmaraş Province (b) Ĭgdır Province; scale bars $1.0 \mathrm{~mm}$

Also, black spots are exhibited on the pronotum similar to those on the frons and on the occiput-vertex. However, especially in the Kahramanmaraş Province specimens, those spots are seen to be different (Fig. 4a, b).

In $P$. dealbata, the spots and the color on the abdomen are very important. While the specimens from Iğdır Province have pale blue abdomen, their abdomen is ivory colored in Kahramanmaraş Province. In both localities (Iğdır and Kahramanmaraş Provinces), the specimens have black spots on the S7-9, but, those spots are observed much less on the Kahramanmaraş Province specimens (Fig. 5a,b). 

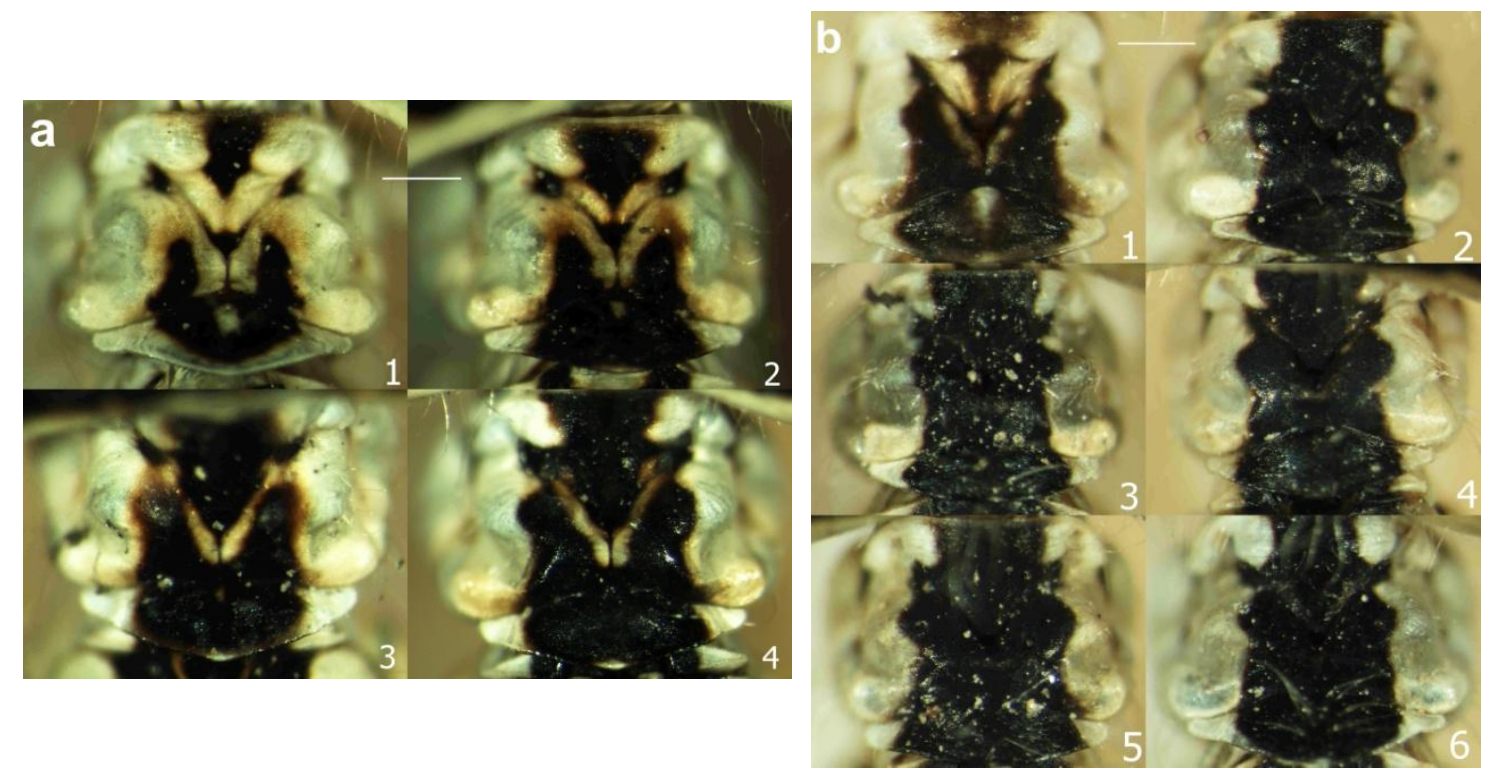

Figure 4. Pronotum dorsal view (a) Kahramanmaraş Province (b) Iğglır Province; scale bars $0.5 \mathrm{~mm}$
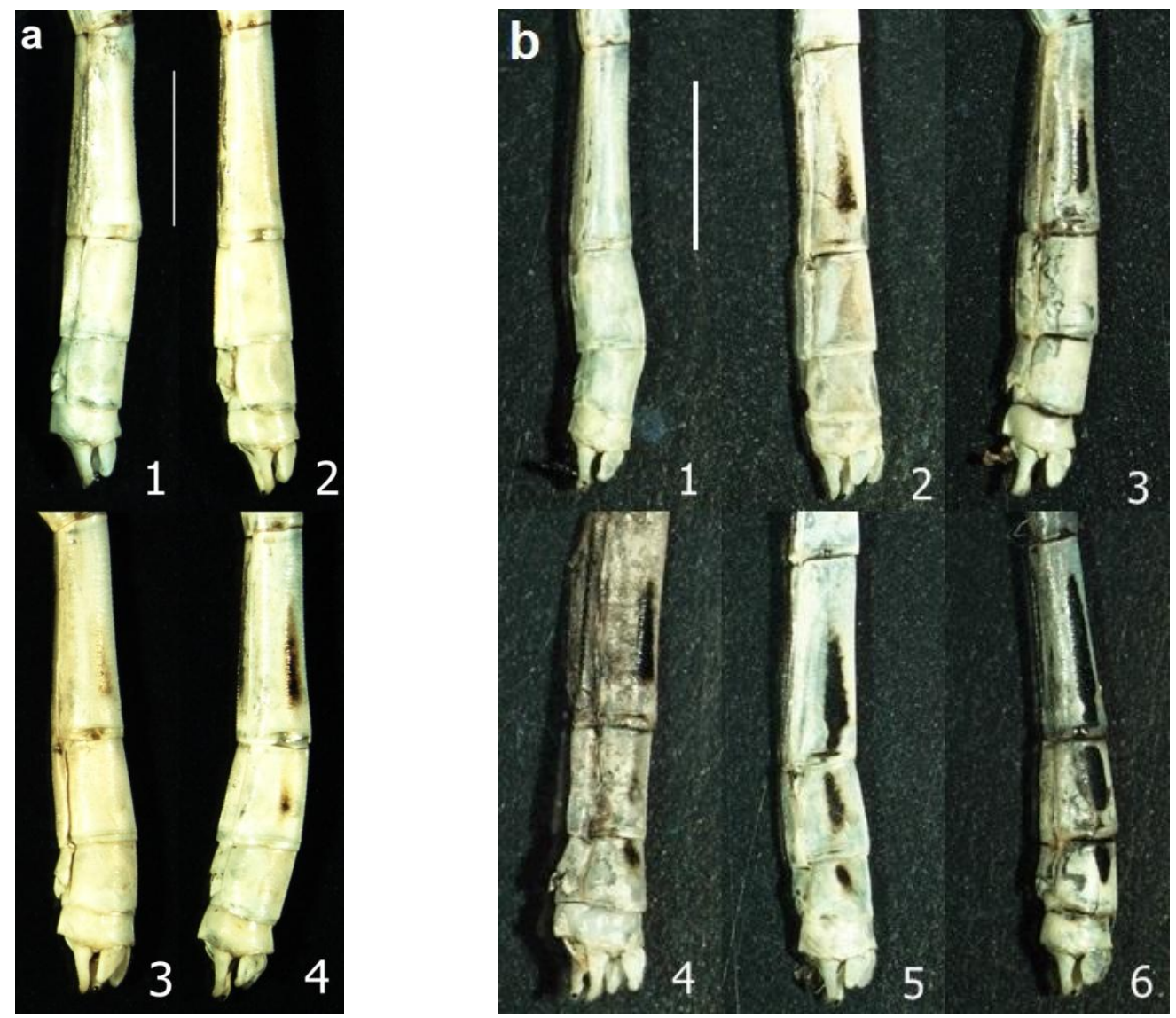

Figure 5. Abdomen (S7-10) lateral view (a) Kahramanmaraş province (b) Iğdır Province; scale bars $2.5 \mathrm{~mm}$ 


\section{Discussion}

In the genus Platycnemis, although many characteristics for identification are taken into account, the most important characteristics are the spots and the color on the abdomen. According to Dijkstra and Lewington (2006), males of these species are identified by their ivory bodies and enlarged white legs. In this case, the abdomen is almost all white, with the S7-9 being seldom marked with black, never with blue and pruinose. Although the S7-9 is marked with black in the examined specimens, it is seldom so. This situation has been determined in many samples. Furthermore, a pale blue abdomen has been observed in the Iğdır Province specimens.

Although differences in color and spots have been observed within the species, there are also differences between the two populations (Kahramanmaraş and Iğdır). Specimens in the Iğdır population have more intense spots than specimens in the Kahramanmaraş population. Besides, Iğdır specimens have pale blue coloration, particularly on the abdomen.

As described previously, the Anatolian Diagonal may lead to diversity in species, and it may also contribute to intraspecific variations. At this point, Kahramanmaras is located in an important region. While Kahramanmaraş is located on the Anatolian Diagonal, Iğdır is found on the eastern part of the Diagonal. According to Çıplak (2008), this region is known as the Maraş triangle, and it is rich in species. At this time, the region has a high intraspecific diversity (Mutun, 2010). It may be considered that the differences (both ecological and geographical) between the two populations (Kahramanmaraş and Iğdır) are probably due to the Anatolian Diagonal.

\section{Conclusion}

Samples should be collected from more regions where $P$. dealbata is distributed to find out whether there are variations in these populations. Phylogenetic studies are also needed to reveal whether there is a genetic diversity between the Kahramanmarass and Iğdır populations.

\section{REFERENCES}

[1] Askew, R. R. (1988): The Dragonflies of Europe. - Harley, Colchelster.

[2] Boudot, J. P., Kalkman, V. J., Amorin, M. A., Bogdanovic, T., Rivera, A. C., Degabriele, G., Dommanget, J. L., Ferreira, S., Garrigos, B., Jovic, M., Kotarac, M., Lopau, W., Marinov, M., Mihokovic, N., Riservato, E., Samraoui, B., Schneider, W. (2009): Atlas of the Odonata of the Mediterranean and North Africa. - Libellula Supplement 9: 1-256.

[3] Çıplak, B, Demirsoy, A., Bozcuk, A. N. (1993): Distribution of Orthoptera in relation to the Anatolian Diagonal in Turkey. - Articulata 8: 1-20.

[4] Çıplak, B. (2008): The Analogy between Interglacial and Global Warming for the Glacial Relicts in a Refugium: A Biogeographic Perspective for Conservation of Anatolian Orthoptera. - In: Fattorini, S. (ed.) Insect Ecology and Conservation. Research Sign Post, Kerala/India.

[5] Davis, P. H. (1971): Distribution Patterns in Anatolia with Particular Reference to Endemism. - In: Davis, P. H., Harper, P. C., Hedge, I. C. (eds): Plant Life of South-West Asia. Botanical Society of Edinburgh, Edinburgh/Scotland.

[6] Dijkstra, K. D. B., Lewington, R. (2006): Field Guide to the Dragonflies of Britain and Europe Including Western Turkey and North-western Africa. - British Wildlife Publishing, Milton on Stour Gillingham. 
[7] Dumont, H. J. (1977): A Review of The dragonfly fauna of Turkey and adjacent Mediterranean islands (Insecta Odonata). - Bulletin et Annales de la Societe Royale Belge d'Entomologie 133: 119-171.

[8] Kalkman, V. J. (2006): Key to the dragonflies of Turkey, including species known from Greece, Bulgaria, Lebanon, Syria, the Trans-Caucasus and Iran. - Brachytron 10: 3-82.

[9] Kalkman, V. J., Wasscher, M., Van Pelt, G. J. (2003): An annotated checklist of the Odonata of Turkey. - Odonatologica 32: 215-236.

[10] Kapli, P., Botoni, D., Ilgaz, Ç., Kumlutaş, Y., Avc1, A., Rastegar-Pouyani, N., Fathini, B., Lymberakis, P., Ahmadzadeh, F., Poulakakis, N. (2013): Molecular phylogeny and historical biogeograhy of the Anatolian lizard Apathya (Squamata, Lacertidae). Molecular Phylogenetics and Evolution 66: 992-1001.

[11] Kiany, M., Sadeghi, S., Ehteshami, F. (2016): New record of Platycnemis kervillei and Lestes dryas (Odonata: Platycnemididae \& Lestidae) from Iran. - 19th National and 7th International Congress of Biology, 30 Aug-1 Sep 2016, University of Tabriz, Iran, 94 pp. [no official publication, congress data without peer review].

[12] Schneider, T., Ikemeyer, D. (2016): Notes on Odonata species in South-West Iran including Platycnemis kervillei (Martin, 1909) as a new species for Iran. Entomologische Zeitschrift 126: 1-8.

[13] Schneider, T., Ikemeyer, D. (2017): Late summer observations on Odonata from the Armenian Highland to the Talysh Mountains in north-west Iran. - Entomologist's Monthly Magazine 153: 1-10.

[14] Martens, A. (1996): Die Federlibellen Europas (Platycnemididae) (Die Neue BrehmBücherei; Bd. 626, Die Libellen Europas 1). - Westarp Wissenschaften, Magdeburg.

[15] Mutun, S. (2010): Intraspecific genetic variation and phylogeography of the oak gallwasp Andricus caputmedusa (Hymenoptera: Cynipidae) Effects of the Anatolian Diagonal. Acta Zoologica Academia Scientiarum Hungaricae 56: 153-172.

[16] Rögl, F. (1998): Paleogeographic considerations for Mediterranean and Paratethys Seaways (Oligocene to Miocene). - Annalen des Naturhistorischen Museums Wien 99(A): 279-310.

[17] Steinmann, H. (1997): World Catalogue of Odonata. Volume I: Zygoptera. - Walter de Gruyter, Berlin. 